\title{
Microvesicles from Human Adipose Tissue- Derived Mesenchymal Stem Cells as a New Protective Strategy in Osteoarthritic Chondrocytes
}

\author{
Miguel Tofiño-Vian ${ }^{a} \quad$ Maria Isabel Guillén ${ }^{a, b} \quad$ María Dolores Pérez del Caz \\ Antonio Silvestre $^{d} \quad$ Maria José Alcaraz ${ }^{\mathrm{a}}$ \\ aInstituto Interuniversitario de Investigación de Reconocimiento Molecular y Desarrollo Tecnológico \\ (IDM), Universitat Politècnica de València, Universitat de València, Valencia, ' $\mathrm{b}$ epartment of Pharmacy, \\ Cardenal Herrera-CEU University, Valencia, 'Department of Burn and Plastic Surgery, La Fe Polytechnic \\ University Hospital, Valencia, dDepartment of Surgery, Faculty of Medicine, University of Valencia, \\ Valencia, Spain
}

\section{Key Words}

Extracellular vesicles - Adipose tissue-derived mesenchymal stem cells - Chondrocyte • Inflammation • Osteoarthritis

\begin{abstract}
Background/Aims: Chronic inflammation contributes to cartilage degeneration during the progression of osteoarthritis (OA). Adipose tissue-derived mesenchymal stem cells (ADMSC) show great potential to treat inflammatory and degradative processes in OA and have demonstrated paracrine effects in chondrocytes. In the present work, we have isolated and characterized the extracellular vesicles from human AD-MSC to investigate their role in the chondroprotective actions of these cells. Methods: AD-MSC were isolated by collagenase treatment from adipose tissue from healthy individuals subjected to abdominal lipectomy surgery. Microvesicles and exosomes were obtained from conditioned medium by filtration and differential centrifugation. Chondrocytes from OA patients were used in primary culture and stimulated with $10 \mathrm{ng} / \mathrm{ml}$ interleukin(IL)- $1 \beta$ in the presence or absence of AD-MSC microvesicles, exosomes or conditioned medium. Protein expression was investigated by ELISA and immunofluorescence, transcription factor-DNA binding by ELISA, gene expression by real-time $P C R$, prostaglandin $E_{2}\left(P_{G} E_{2}\right)$ by radioimmunoassay, and matrix metalloproteinase (MMP) activity and nitric oxide (NO) production by fluorometry. Results: In OA chondrocytes stimulated with IL-1 $\beta$, microvesicles and exosomes reduced the production of inflammatory mediators tumor necrosis factor- $\alpha, \mathrm{IL}-6, \mathrm{PGE}_{2}$ and NO. The downregulation of cyclooxygenase- 2 and microsomal prostaglandin $E$ synthase-1 would lead to the decreased $\mathrm{PGE}_{2}$ production while the effect on NO could depend on the reduction of inducible nitric oxide synthase M. I. Guillén and M. J. Alcaraz contributed equally to this work.

María José Alcaraz

Instituto Interuniversitario de Investigación de Reconocimiento Molecular y Desarrollo Tecnológico Universitat Politècnica de València, Universitat de València, Av. Vicent A. Estellés s/n, 46100 Burjasot, Valencia (Spain); E-Mail maria.j.alcaraz@uv.es
\end{abstract}

KARGER 
expression. Treatment of $\mathrm{OA}$ chondrocytes with extracellular vesicles also decreased the release of MMP activity and MMP-13 expression whereas the production of the anti-inflammatory cytokine IL-10 and the expression of collagen II were significantly enhanced. The reduction of inflammatory and catabolic mediators could be the consequence of a lower activation of nuclear factor- $\mathrm{KB}$ and activator protein-1. The upregulation of annexin A1 specially in MV may contribute to the anti-inflammatory and chondroprotective effects of AD-MSC. Conclusions: Our data support the interest of AD-MSC extracellular vesicles to develop new therapeutic approaches in joint conditions.

(C) 2018 The Author(s)

Published by S. Karger AG, Basel

\section{Introduction}

Chronic production of inflammatory mediators has important implications for chondrocyte metabolism in joint diseases. Pro-inflammatory cytokines contribute to alterations in osteoarthritis $(\mathrm{OA})$ joint metabolism through the production of inflammatory mediators and catabolic enzymes capable of destroying cartilage matrix [1-3], and the downregulation of anti-inflammatory and anabolic genes [4]. OA remains a leading cause of disability in the elderly without an effective treatment. At present, the treatment of $\mathrm{OA}$ is targeted to control symptoms although innovative therapeutic approaches such as joint injection of mesenchymal stem cells (MSC) and differentiation into chondrocytes using appropriate scaffolds to regenerate cartilage are being investigated [5].

MSC have opened a new avenue for treating tissue injury and inflammation. In particular, adipose tissue-derived mesenchymal stem cells (AD-MSC) show great therapeutic potential and have demonstrated protective properties in animal models of OA. Therefore, injection of these cells into the knee joint is able to reduce inflammation and cartilage degradation induced by collagenase in mice [6] or by anterior cruciate ligament transection in rabbits [7].

MSC cell therapy has demonstrated beneficial effects despite short-lived survival of the delivered cells suggesting that secreted factors may be the active components. There is evidence that MSC secrete into their microenvironment a number of cytokines and growth factors that regulate intracellular signaling pathways in neighboring cells, promote angiogenesis and recruitment of stem/progenitor cells, or exert trophic and immunomodulatory effects (reviewed in [8]). As a result, treatment of OA chondrocytes or synovial cells with conditioned medium (CM) from bone marrow MSC or AD-MSC in an inflammatory environment can inhibit the production of inflammatory and catabolic agents $[9,10]$.

It is now recognized that MSC release extracellular vesicles (EV) as vehicles for intercellular communication. In particular, microvesicles (MV) are a heterogeneous population of spherical structures with a diameter of 100-1000 nm which are released by ectocytosis of the plasma membrane [11] while exosomes (EX) are membrane vesicles with a diameter of 40-100 nm, formed by endocytosis, stored intracellularly and secreted when endosomal structures fuse with the plasma membrane [12]. In recent years, there has been significant interest in MSC EV as mediators of regenerative responses with potential therapeutic applications in cardiovascular diseases [13], rheumatic diseases [14], fracture healing [15], neurodegeneration [16] or immunomodulation [17]. In relation with cartilage metabolism, it has been shown recently that EX from HuES9 human embryonic stem cells are able to repair osteochondral defects in rats [18] and EX from miR-140-5poverexpressing human synovial MSC prevent the development of OA-like changes after surgical destabilization of the rat knee [19].

We have previously reported the anti-inflammatory and protective properties of CM from AD-MSC in OA chondrocytes $[20,21]$. Despite these studies, the possible contribution of EV to the observed effects is not known. To address this issue, we have assessed how MV and EX isolated from this CM could affect the metabolism of OA chondrocytes by modulating inflammatory and degradative pathways relevant in joint destruction. 


\section{Cellular Physiology Cell Physiol Biochem 2018:47:11-25 and Biochemistry Publisned onIIne: IVlay 15, $2018 \quad$\begin{tabular}{l|l} 
DOI: 10.1159/000489739 & $\begin{array}{l}\text { (c) } 2018 \text { The Author(s). Published by S. Karger AG, Basel } \\
\text { www.karger.com/cpb }\end{array}$
\end{tabular} \\ Tofiño-Vian et al.: Chondroprotective Actions of AD-MSC MV}

\section{Materials and Methods}

Adipose tissue-derived mesenchymal stem cells

AD-MSC were obtained from the adipose tissue of 10 non-obese donors ( 4 men and 7 women, aged $53.8 \pm 7.4$ years, mean \pm SEM) who had undergone abdominoplasty. The experimental design was approved by the Institutional Ethical Committees (University of Valencia and La Fe Polytechnic University Hospital, Valencia, Spain). Samples were obtained from donors after they provided informed consent according to the Helsinki Declaration of 1975, as revised in 2013.

Adipose tissue samples were washed with phosphate-buffered saline (PBS), minced, digested at $37^{\circ} \mathrm{C}$ for $1 \mathrm{~h}$ with $2 \%$ of type I collagenase (Gibco, Life Technologies, Madrid, Spain) and filtered through a $100 \mu \mathrm{m}$ cell strainer (BD Biosciences, Bedford, MA, USA). Then, cells were washed with DMEM/HAM F12 (SigmaAldrich, St. Louis, MO, USA) containing penicillin and streptomycin (1\%), seeded onto tissue culture flasks $\left(1-2 \times 10^{6}\right.$ cells $\left./ \mathrm{ml}\right)$ in DMEM/HAM F12 medium with penicillin and streptomycin (1\%) supplemented with $15 \%$ EV-free human serum, and incubated at $37^{\circ} \mathrm{C}$ in a $5 \% \mathrm{CO}_{2}$ atmosphere. Human serum was obtained from whole-blood donations of AB-blood-group-typed donors according to the criteria of Valencia Transfusion Centre. To eliminate the EV fraction, serum was centrifuged during $18 \mathrm{~h}$ at $120,000 \times \mathrm{g}$ and $4^{\circ} \mathrm{C}$ using a SW28 swinging-bucket rotor (Beckman Coulter, Brea, CA, USA). At $24 \mathrm{~h}$, when cells reached semiconfluence, culture plates were washed and the AD-MSC phenotype confirmed by flow cytometry (Flow Cytometer II, BD Biosciences, San Jose, CA, USA) using specific antibodies: anti-CD105-PE, antiCD90PerCP-eFluo 710, antiCD34APC (eBioscience, Inc., San Diego, CA, USA), and anti-CD45-PE (BD Pharmingen ${ }^{\mathrm{TM}}$, BD Biosciences). Cellular viability was determined with propidium iodide.

Immortalized Human Keratinocytes (HaCaT) cell line was kindly provided by Prof. Norbert E. Fusenig (German Cancer Research Institute, Heidelberg, Germany). Cells were cultured in DMEM/HAM F12 with penicillin and streptomycin (1\%) supplemented with 15\% EV-free human serum, and incubated at $37^{\circ} \mathrm{C}$ in a $5 \% \mathrm{CO}_{2}$ atmosphere.

$\mathrm{CM}$ was collected from AD-MSC and HaCaT culture cells at passage 0 every $48 \mathrm{~h}$ of culture. It was pooled, centrifuged, and stored in sterile conditions at $-80^{\circ} \mathrm{C}$ prior to further use.

\section{Isolation of EV}

EV were obtained from the CM of AD-MSC and HaCaT cells using a filtration/centrifugation-based protocol. Cellular debris was eliminated by pelleting with centrifugation at $300 \times \mathrm{g}$ for $10 \mathrm{~min}$ at $4^{\circ} \mathrm{C}$. EV were then collected from the supernatant through differential centrifugation steps. Briefly, CM was filtered through $800 \mathrm{~nm}$ filter (Merck, Darmstadt, Germany) and centrifuged at $12,200 \times \mathrm{g}$ for $20 \mathrm{~min}$ at $4^{\circ} \mathrm{C}$ to pellet MV. Then, supernatants were filtered through $200 \mathrm{~nm}$ filter (Merck, Darmstadt, Germany) and centrifuged at $100,000 \times \mathrm{g}$ for $90 \mathrm{~min}$ at $4^{\circ} \mathrm{C}$. The resulting pellets containing EX were washed once with sterile PBS, resuspended in $15 \mu \mathrm{l}$ of $\mathrm{PBS}$ and stored at $-80^{\circ} \mathrm{C}$ until use.

Tunable resistive pulse sensing (TRPS)

EV preparations were analyzed by TRPS using a qNano instrument (IZON Sciences Ltd., Oxford, UK) [22]. NP100, and NP300 nanopore membranes were used to measure the samples of EX and MV, respectively. At least 500 events/sample were counted. Calibration was performed using calibration beads SKP200 and SKP400, provided by the manufacturer.

\section{Transmission electron microscopy (TEM)}

EV preparation for TEM was performed by the Microscopy Service (SCSIE, University of Valencia). Briefly, LR-white resin inclusion was performed fixing EV samples with Karnovsky fixative, inclusion in agar, followed by water washing and dehydration in 30\% EtOH, 50\% EtOH, 70\% EtOH and 96\% EtOH. Finally, samples were sequentially incubated for $2 \mathrm{~h}$ in 33\% LR-white resin in 96\% EtOH, 66\% LR-white resin in 96\% EtOH, 66\% LR-white resin in 100\% EtOH and 100\% LR-white resin in 100\% EtOH. Samples were filtered in resin and polymerized at $60^{\circ} \mathrm{C}$ for $48 \mathrm{~h}$. Then, ultrathin slices $(60 \mathrm{~nm})$ were made with a diamond blade (DIATOME, Hartfield, USA) in eyelet grilles in a UC6 Ultracut (Leica, Wetzlar, Germany) and stained with uranyl acetate $2 \%$ for $25 \mathrm{~min}$ and lead citrate 3\% for another $12 \mathrm{~min}$ prior to visualization in Jeol-1010 (JEOL Ltd. Tokyo, Japan) at $60 \mathrm{kV}$. Images were acquired with a digital camera MegaView III with Olympus Image Analysis Software (Olympus, Tokyo, Japan). 


\section{Cellular Physiology Cell Physiol Biochem 2018:47:11-25 and Biochemistry Published onIIne: IVay 15, $2018 \quad$\begin{tabular}{l|l} 
DOI: 10.1159/000489739 2018 The Author(s). Published by S. Karger AG, Basel \\
www.karger.com/cpb
\end{tabular} \\ Tofiño-Vian et al.: Chondroprotective Actions of AD-MSC MV}

For gold-immunostaining, mouse anti-human CD63 monoclonal and goat anti-mouse IgG H\&L (10 nm Gold) polyclonal antibodies from Abcam (Cambridge, MA, USA) were used. EV were fixed with Karnovsky's fixative and then processed in resin as described above. Grids containing the samples were blocked with PBS $/ 0.8 \%$ bovine serum albumin (BSA) $/ 0.1 \%$ gelatin, and $2 \mu \mathrm{l}$ of primary antibody in PBS $/ 0.5 \%$ BSA were added. Grids were then washed with PBS $/ 0.5 \%$ BSA, incubated with the gold-labeled secondary antibody in PBS $/ 0.5 \%$ BSA for $30 \mathrm{~min}$, and then washed in $100 \mu \mathrm{l}$ drops of PBS/0.5\% BSA. Control grids incubated with only secondary antibodies were also used. The grids were stained with $2 \%$ uranyl acetate and then viewed for TEM using a Jeol JEM1010 microscope at $60 \mathrm{kV}$ and images were acquired with a digital camera MegaView III with Olympus Image Analysis Software.

\section{Flow Cytometry}

Annexin V positive MV were determined with the FITC Annexin V Detection Kit I (BD Biosciences). Immediately before incubation, antibody was ultracentrifuged and washed in $0.2 \mu \mathrm{m}$ filtered-PBS to avoid noise, and all solutions were previously filtered. For labeling, EV were diluted down to 500, 000 particles/ $\mathrm{ml}$ in labeling buffer with FITC-conjugated annexin $\mathrm{V}$ and incubated at room temperature for $1 \mathrm{~h}$ in dark. After labeling, EV were twice washed and recovered in filtered PBS. EV were then analyzed at a flow rate on a LSR Fortessa X-20 flow cytometer (BD Biosciences) and data registered with the software DIVA 8.0 processed with the software FlowJo (FlowJo LLC, Ashland, OR, USA). The gating window for counting EV and discriminating against background noise was set using forward and side scatter plots for Megamix-Plus FSC fluorescent beads (BioCytex, Marseille, France) of diameters $100 \mathrm{~nm}, 300 \mathrm{~nm}, 500 \mathrm{~nm}$ and $900 \mathrm{~nm}$, and FITC fluorescent positivity established as compared to unlabeled EV and EV-free annexin V and FITCantibody solutions.

\section{OA chondrocytes}

Knee specimens were obtained from patients diagnosed with advanced OA (27 women and 14 men, aged $65.6 \pm 12.0$ years, mean \pm SEM) who had undergone total joint replacement. The experimental design was approved by the Institutional Ethical Committees as indicated above. Cartilage was dissected from the femoral condyles and tibial plateau of the knee joint and diced into small pieces. Human articular chondrocytes were isolated by sequential enzymatic digestion: $1 \mathrm{~h}$ with $0.1 \mathrm{mg} / \mathrm{ml}$ hyaluronidase (Sigma-Aldrich) followed by $12-15 \mathrm{~h}$ with $2 \mathrm{mg} / \mathrm{ml}$ type IA collagenase (Sigma-Aldrich) in DMEM/HAM F12 containing penicillin and streptomycin (1\%) at $37^{\circ} \mathrm{C}$ in $5 \% \mathrm{CO}_{2}$ atmosphere. The digested tissue was filtered through a $70 \mu \mathrm{m}$ nylon mesh (BD Biosciences), washed, and centrifuged. Cell viability was greater than $95 \%$ according to the Trypan blue exclusion test. All experiments were performed with chondrocyte primary cultures at semiconfluence $\left(270 \times 10^{3}\right.$ cells/well in 6 -well plates or $1.5 \times 10^{6}$ cells in $3.5 \mathrm{~cm}$ plates). Chondrocytes were maintained with $5 \% \mathrm{CO}_{2}$ at $37^{\circ} \mathrm{C}$ in DMEM/HAM F12 containing penicillin and streptomycin (1\%), supplemented with $10 \%$ fetal bovine serum (Sigma-Aldrich).

To perform the experiments, chondrocytes and explants were incubated for different times in DMEM/ HAM F12 containing penicillin and streptomycin (1\%) supplemented with 15\% EV-free human serum and stimulated with interleukin(IL)-1 $\beta(10 \mathrm{ng} / \mathrm{ml})$ in the presence or absence of AD-MSC- or HaCaT MV $\left(3.6 \times 10^{7}\right.$ particles/ml), EX ( $7.2 \times 10^{7}$ particles $\left./ \mathrm{ml}\right)$ or CM $(0.4 \mathrm{ml}$ for 24-well plates, $1 \mathrm{ml}$ for 6-well plates or $1.5 \mathrm{ml}$ for $3.5 \mathrm{~cm}$ plates).

For explant cultures, full-thickness pieces of cartilage were removed from the femoral condyles. Slices measuring $\sim 2 \mathrm{~mm}$ in width $\times 2 \mathrm{~mm}$ in length were dissected from the tissue. Explants were transferred to 24-well plates (10 explants/well) containing DMEM/HAM F12 medium supplemented with penicillin and streptomycin (1\%), and $10 \%$ fetal bovine serum, and they were incubated in a humidified $5 \% \mathrm{CO}_{2}$ incubator at $37^{\circ} \mathrm{C}$ for 2 days before assays to allow them to stabilize.

\section{MTT Assay}

The mitochondrial dependent reduction of 3-(4, 5-dimethylthiazol-2-yl)-2, 5 diphenyltetrazolium bromide (MTT) to formazan was assayed in OA chondrocytes stimulated with IL-1 $\beta(10 \mathrm{ng} / \mathrm{ml})$ and treated

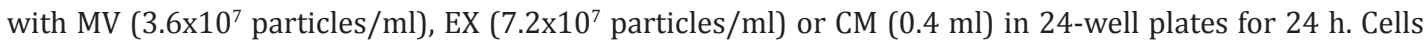
were then incubated with MTT $(200 \mu \mathrm{g} / \mathrm{ml})$ for $2 \mathrm{~h}$. Medium was removed and cells were solubilized in dimethyl sulfoxide $(100 \mu \mathrm{l})$ to quantitate formazan at $550 \mathrm{~nm}$ using a Victor 3 microplate reader (PerkinElmer España, Madrid, Spain). 


\section{Cellular Physiology Cell Physiol Biochem 2018:47:11-25 \begin{tabular}{ll|l} 
and Biochemistry Published onIIne: IVlay 15, 2018 & $\begin{array}{l}\text { C } 2018 \text { The Author(s). Published by S. Karger AG, Basel } \\
\text { www.karger.com/cpb }\end{array}$
\end{tabular} \\ Tofiño-Vian et al.: Chondroprotective Actions of AD-MSC MV}

\section{Proteomic analysis of EV by mass spectrometry}

Proteomic characterization of EV samples was performed by the Proteomics Service of the Servei Central de Suport a la Investigació Experimental (Universitat de València). Briefly, $10 \mu \mathrm{g}$ per EV sample were digested with Triton X-100 and separated by 1-D SDS PAGE. Peptides were generated by a trypsin digestion, extracted, and examined by LC using a NanoLC Ultra 1-D plus Exsigent (Eksigent Technologies, Dublin, CA, USA) which was directly connected to an AB SCIEX TripleTOF 5600 mass spectrometer (AB SCIEX, Framingham, MA, USA) in direct injection mode. After LC-MS/MS, the SCIEX.wiff data-files were processed using ProteinPilot v5.0 search engine (AB SCIEX). The resulting ProteinPilot group file was loaded into PeakView ${ }^{\circledR}$ (v2.1, AB SCIEX) and peaks were extracted with a peptide confidence threshold of $99 \%$ confidence (Unused Score $\geq 1.3$ ) and a false discovery rate (FDR) lower than $1 \%$. For this, the MS/ MS spectra of the assigned peptides were extracted by ProteinPilot, and only the proteins that fulfilled the following criteria were validated: (1) peptide mass tolerance lower than $10 \mathrm{ppm}$, (2) 99\% of confidence level in peptide identification, and (3) complete b/y ions series found in the MS/MS spectrum. The identified proteins were quantified using PeakView ${ }^{\circledR}$ from normalized label-free quantification (LFQ) intensity data. The quantitative data obtained by PeakView® were analyzed using MarkerView $®$ (v1.2, AB SCIEX). First, areas were normalized by total areas summa. Principal Component Analysis (PCA) was performed to evaluate the discriminative ability of proteins in different EV fractions. Bioinformatics analysis of identified and validated SP-proteins was manually performed using the comprehensive bioinformatics tool for functional annotation UniProt KB database (www.uniprot.org) in combination with PANTHER (www.pantherdb.org) and FunRich (http://www.funrich.org). Data are available via ProteomeXchange with identifier PXD009077 and 10.6019/PXD009077.

\section{ELISA}

Chondrocytes were stimulated with IL- $1 \beta(10 \mathrm{ng} / \mathrm{ml})$ in presence or absence of MV $\left(3.6 \times 10^{7}\right.$ particles/ $\mathrm{ml})$, EX ( $7.2 \times 10^{7}$ particles $\left./ \mathrm{ml}\right)$ or $\mathrm{CM}(1 \mathrm{ml})$ for $24 \mathrm{~h}$, or $1 \mathrm{~h}$ for transcription factors detection. Supernatants were centrifuged and stored at $-80^{\circ} \mathrm{C}$ until analysis. Tumor necrosis factor- $\alpha(\mathrm{TNF} \alpha)$, IL-6, and IL-10 were measured by enzyme-linked immunosorbent assay (ELISA) kits from eBioscience (San Diego, CA, USA) with a sensitivity of $4.0 \mathrm{pg} / \mathrm{ml}$ for TNF $\alpha$ and IL-6, and $2.0 \mathrm{pg} / \mathrm{ml}$ for IL-10. Nuclear factor- $\mathrm{KB}$ (NF- $\mathrm{\kappa B}$ ) and activator protein-1 (AP-1) binding to DNA was quantified by ELISA in nuclear extracts using the Nuclear Extract Kit Active Motif for nuclei extraction followed by TransAM p65 NF- $\mathrm{KB}$ and TransAM c-Jun Activation Assay kits (Active Motif Europe, Rixensart, Belgium), according to the manufacturer's recommendations.

\section{Determination of MMP activity, $N O$ and $P G E_{2}$}

Chondrocytes were stimulated as indicated above and supernatants were harvested and centrifuged. For matrix metalloproteinase (MMP) activity determination, supernatants were incubated with $\mathrm{p}$-aminophenylmercuric acetate for $12 \mathrm{~h}$ at $37^{\circ} \mathrm{C}$ to activate MMPs. Then, supernatants were transferred to a 96-well plate. After addition of the 5- FAM peptide substrate (AnaSpec Inc., San Jose, CA, USA), fluorescence was measured at $490 \mathrm{~nm}$ (excitation)/520 nm (emission) in a Victor3 microplate reader (PerkinElmer España). Prostaglandin $\mathrm{E}_{2}\left(\mathrm{PGE}_{2}\right)$ was quantitated in supernatants by radioimmunoassay [23] and nitric oxide (NO) production was assessed by fluorometric determination of nitrite levels [24] using a Victor3 microplate reader (PerkinElmer España).

\section{Real-time PCR}

Total RNA was extracted from OA chondrocytes using the TriPure reagent (Roche Life Science, Barcelona, Spain) according to the manufacturer's instructions. Reverse transcription was accomplished on $1 \mu \mathrm{g}$ of total RNA using random primers and Transcriptor First Strand cDNA Synthesis Kit (Roche Life Science). PCR assays were performed in duplicate on an iCycler Real-Time PCR Detection System using SYBR Green PCR Master Mix (Bio-Rad Laboratories, Richmond, CA, USA). Primers were synthesized by Eurofins MWG Operon (Ebersberg, Germany) [20]. For each sample, differences in threshold cycle ( $\Delta \mathrm{Ct}$ ) values were calculated by correcting the $\mathrm{Ct}$ of the gene of interest to the $\mathrm{Ct}$ of the reference gene $\beta$-actin. Relative gene expression was expressed as $2^{-\Delta \Delta C t}$ with respect to non-stimulated cells.

\section{Immunofluorescence}

Chondrocytes were seeded at $20 \times 10^{3}$ cells/well in Lab-tek chambers (Thermo Scientific, Rochester, NY, USA $)$ and stimulated with IL- $1 \beta(10 \mathrm{ng} / \mathrm{ml})$ in the presence or absence of MV $\left(3.6 \times 10^{7}\right.$ particles $\left./ \mathrm{ml}\right), \mathrm{EX}$ $\left(7.2 \times 10^{7}\right.$ particles $\left./ \mathrm{ml}\right)$ or $\mathrm{CM}(0.2 \mathrm{ml})$ for $24 \mathrm{~h}$ (annexin A1) or 5 days (collagen II). Cells were fixed with $4 \%$ 


\section{Cellular Physiology Cell Physiol Biochem 2018:47:11-25

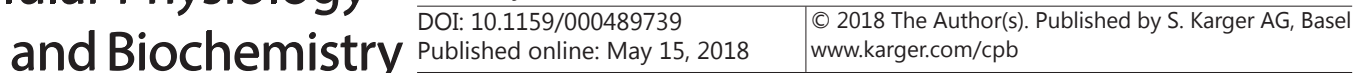 \\ Tofiño-Vian et al.: Chondroprotective Actions of AD-MSC MV}

formaldehyde in PBS for 30 min at $4^{\circ} \mathrm{C}$, blocked with 1\% BSA in PBS for 20 min at room temperature and incubated with rabbit anti-human type II collagen polyclonal antibody (Chemicon/Millipore, Schwalbach, Germany) or MaxPab rabbit anti-annexin A1 polyclonal antibody (Abnova, New Taipei, Taiwan) followed by incubation with goat anti-rabbit IgG-FITC (R\&D Biosystems, Abingdon, UK). Slides were mounted in Prolong Gold antifade reagent with DAPI (Molecular Probes, Invitrogen, Life Technologies) and examined under a confocal microscope (Olympus FV1000, Tokyo, Japan). Collagen II- or annexin A1-positive cells were observed in 6 microscopic fields of each well. Fluorescence density was quantified using Image software (National Institutes of Health, USA).

\section{Annexin A1 blocking}

MV were incubated with MaxPab rabbit anti-ANXA1 polyclonal antibody (Abnova, New Taipei, Taiwan) at $20 \mu \mathrm{g} / \mathrm{ml}$ for $1 \mathrm{~h}$ at $4^{\circ} \mathrm{C}$, then washed with PBS and pelleted at $12.600 \times \mathrm{g}$. Chondrocytes were stimulated with IL-1 $\beta(10 \mathrm{ng} / \mathrm{ml})$ in presence or absence of MV $\left(3.6 \times 10^{7}\right.$ particles $\left./ \mathrm{ml}\right)$ previously treated with antiannexin A1 antibody or MV control for 24 h. IL- 6 was determined in supernatants by ELISA and collagen type-II in chondrocytes by immunofluorescence as indicated above.

\section{Statistical analysis}

Data are expressed as mean and standard error of the mean (mean \pm SEM). Data were analyzed by oneway analysis of variance (ANOVA) followed by the Sidak's post test using the GraphPad Prism 7.0 software (Graph Pad Software, La Jolla, CA, USA). A $P$ value of less than 0.05 was considered statistically significant.

\section{Results}

Characterization of EV and effect on cell viability

MV and EX fractions were isolated from ADMSC CM as indicated in Materials and methods. TRPS analysis indicated a mean concentration of MV and EX of $8.0 \times 10^{9}$ and $3.8 \times 10^{10}$ particles/ $\mathrm{ml}$, respectively. In addition, we isolated MV and EX from HaCaT cells as a negative control in functional studies. The MV fraction had an average size of $279 \pm 94 \mathrm{~nm}$ and a concentration of $6.5 \times 10^{10}$ particles $/ \mathrm{ml}$ while the EX fraction had an average size of $104 \pm 19 \mathrm{~nm}$ and a concentration of $1.1 \times 10^{12}$ particles $/ \mathrm{ml}$.

Representative TEM images of MV and EX from AD-MSC with estimated size are shown in Fig. 1A. Immunostaining with gold-labeled anti-CD63 antibodies was performed and we observed the presence of CD63 labeling in EX (Fig. 1B). In addition, $56.7 \pm 16.4 \%(n=3)$ of annexin $\mathrm{V}$ positive MV were detected by flow cytometry. To assess the effects of EV on $\mathrm{OA}$ chondrocytes, we selected the concentrations of $3.6 \times 10^{7}$ particles $/ \mathrm{ml}$ for $\mathrm{MV}$ and $7.2 \times 10^{7}$ particles/ml for EX which are in the range of concentrations present in CM used in the same experiments. We confirmed that MV and EX at these concentrations do not affect cell viability by the MTT method (Fig. 1C).

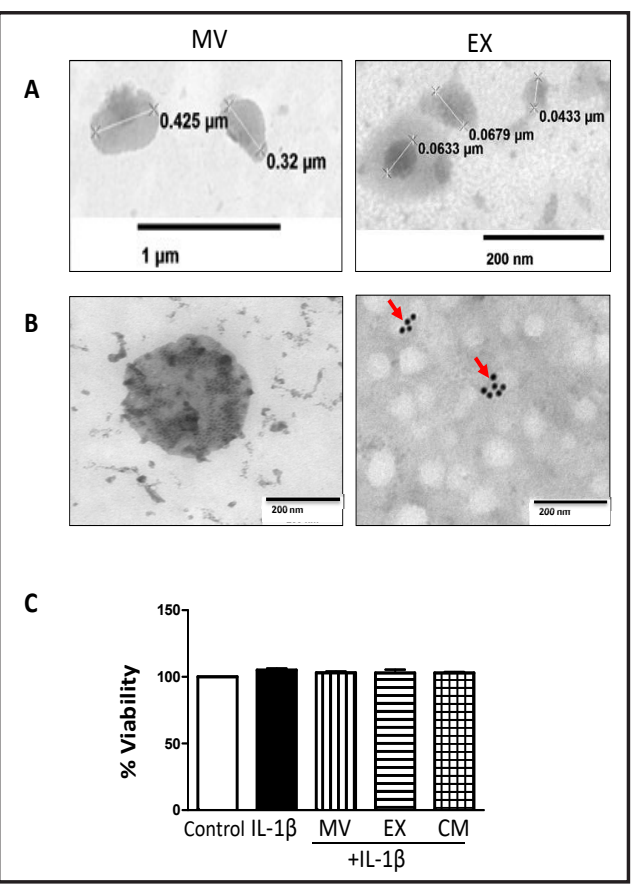

Fig. 1. Characterization of MV and EX isolated from CM from AD-MSC and effect on cell viability. Representative transmission electron microscopy images of MV and EX with estimated size (A). Immunostaining with gold-labeled anti-CD63 antibodies (B). Red arrows show positive staining. C: Viability (\%) of OA chondrocytes in the presence of IL- $1 \beta$ and AD-MSC EV, determined by the MTT method. Results are expressed as mean \pm SEM from 3 separate experiments with cells from separate donors. 


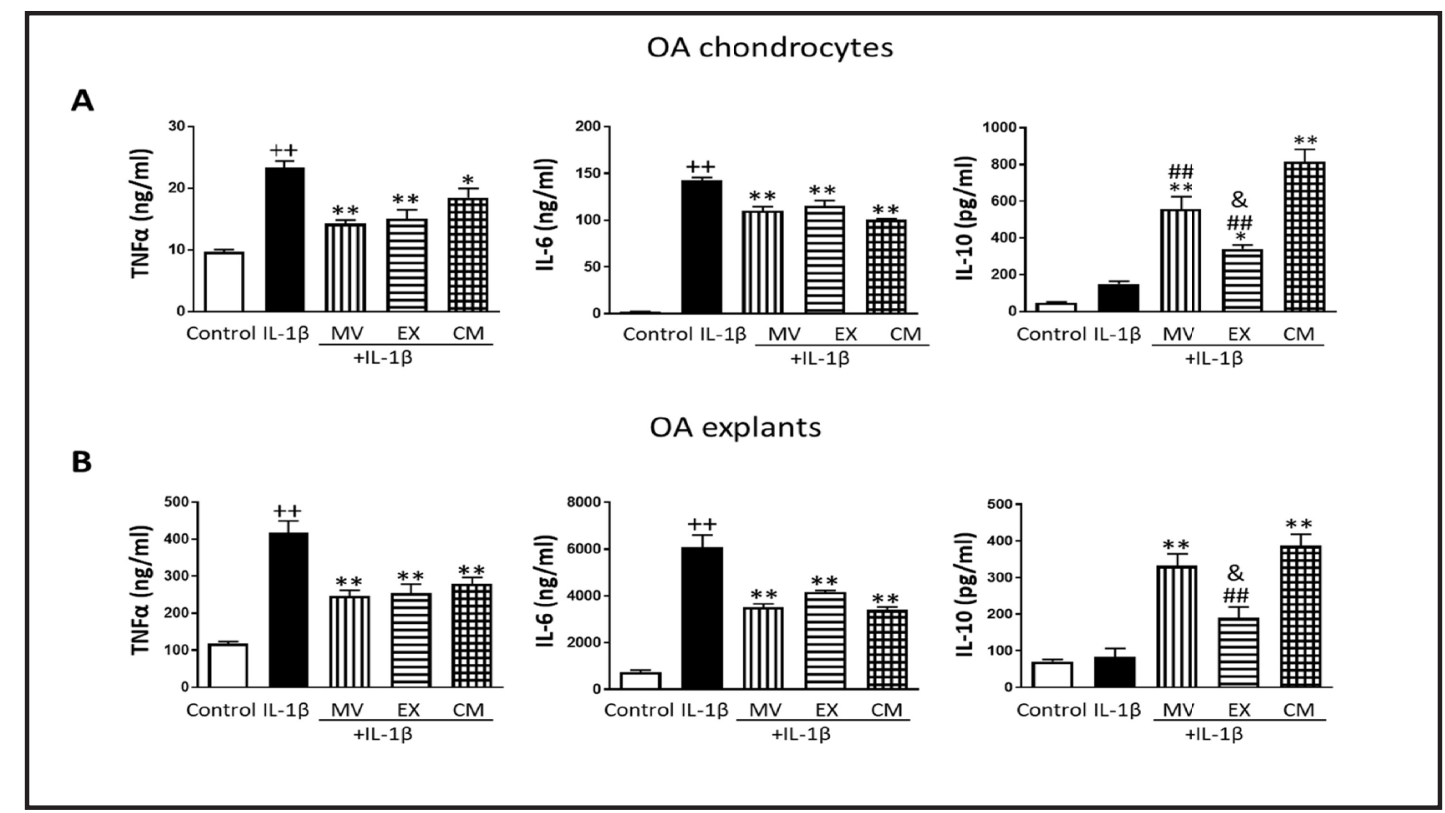

Fig. 2. Effects of $E V$ and $C M$ from $A D-M S C$ on cytokine release by $O A$ chondrocytes $(A)$ and explants (B). IL-6, TNF $\alpha$ and IL-10 were measured by ELISA in culture supernatants. Cultures were treated with IL-1 $\beta$ alone or in combination with EV or CM from AD-MSC for $24 \mathrm{~h}$. Results are expressed as mean \pm SEM from 3 separate experiments with cells from separate donors. ${ }^{++} \mathrm{P}<0.01$ compared to control (non-stimulated cells); ${ }^{*} \mathrm{P}<0.05$, ** $\mathrm{P}<0.01$ compared to IL-1 $\beta$; $\# \# \mathrm{P}<0.01$ compared to $\mathrm{CM}$; ${ }^{\circledR} \mathrm{P}<0.05$ compared to MV.

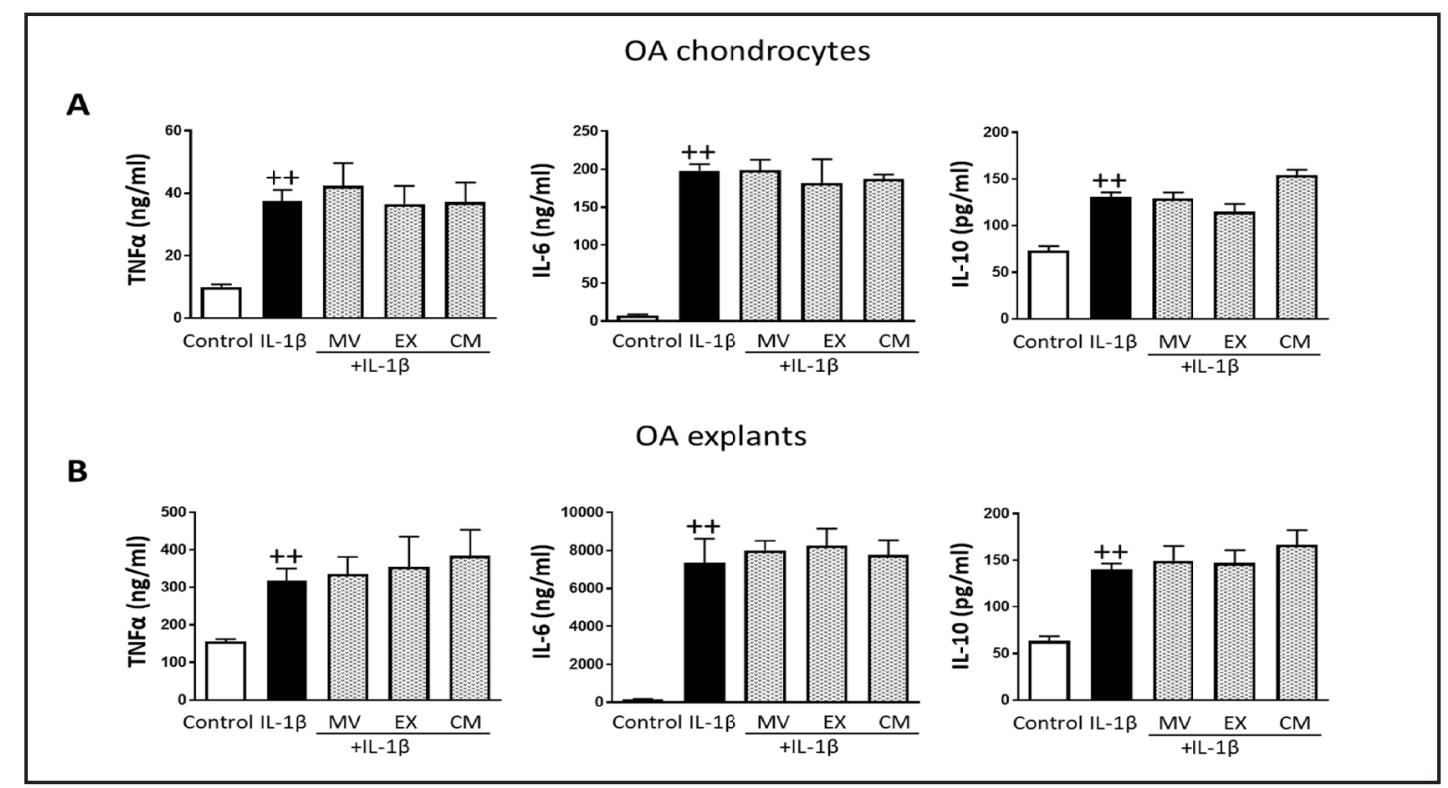

Fig. 3. Effects of EV and CM from HaCaT cells on cytokine release by OA chondrocytes (A) and explants (B). IL-6, TNF $\alpha$ and IL-10 were measured by ELISA in culture supernatants. Cultures were treated with IL-1 $\beta$ alone or in combination with $\mathrm{EV}$ or $\mathrm{CM}$ from $\mathrm{HaCaT}$ cells for $24 \mathrm{~h}$. Results are expressed as mean $\pm \mathrm{SEM}$ from 3 separate experiments with cells from separate donors. ${ }^{++} \mathrm{P}<0.01$ compared to control (non-stimulated cells).

\section{Effects on cytokines}

To study how the production of relevant inflammatory and catabolic mediators was modulated by AD-MSC-derived EV, OA chondrocytes were incubated with IL-1 $\beta$ in the 
presence or absence of MV, EX or CM. Stimulation of OA chondrocytes with IL-1 $\beta$ for $24 \mathrm{~h}$ increased the release of the proinflammatory cytokines IL- 6 and TNF $\alpha$ into the culture medium compared with control non-stimulated cells (Fig. 2A). Treatment with MV, EX or CM significantly reduced the levels of both pro-inflammatory cytokines. In contrast, the release of the anti-inflammatory cytokine IL-10 was significantly enhanced when cells were treated with MV, EX or CM compared with cells treated with IL-1 $\beta$ alone. The highest effect was exhibited by CM followed by MV. In addition, we determined the effects of AD-MSC EV on cytokine production by $\mathrm{OA}$ explants which represent a more physiological setting for chondrocytes. As shown in Fig. 2B, the behavior of MV, EX and $\mathrm{CM}$ in OA explants was very similar to that observed in $\mathrm{OA}$ chondrocytes. In order to determine if these effects of MV and EX are specific to EV from AD-MSC, we performed the same experiments in OA chondrocytes and $\mathrm{OA}$ explants but using $\mathrm{EV}$ and $\mathrm{CM}$ from HaCaT cells instead of AD-MSC. Fig. $3 \mathrm{~A}$ and $\mathrm{B}$ shows that $\mathrm{MV}, \mathrm{EX}$ and $\mathrm{CM}$ from HaCaT cells were completely ineffective on cytokine production by OA chondrocytes or explants.

\section{Effects on $P G E_{2}$ production and COX-2} and $m P G E S-1$ expression

The levels of $\mathrm{PGE}_{2}$ released into the culture medium of $\mathrm{OA}$ chondrocytes were determined to assess if this eicosanoid could be regulated by EV. As shown in Fig. 4A, $\mathrm{PGE}_{2}$ levels in IL-1 $\beta$-stimulated cells were significantly decreased by all treatments. IL$1 \beta$ upregulates cyclooxygenase-2 (COX-2) and microsomal prostaglandin E synthase-1 (mPGES-1) which act in a coordinated manner to synthesize high levels of $\mathrm{PGE}_{2}$ during inflammatory responses [25]. We determined the mRNA expression of COX-2 (Fig. 4B) and mPGES-1 (Fig. 4C) in OA chondrocytes which was reduced by treatment with $\mathrm{EV}$ or $\mathrm{CM}$.

\section{Effects on NO production and iNOS expression}

IL-1 $\beta$ stimulation of OA chondrocytes results in upregulation of inducible nitric oxide synthase (iNOS) and NO production which was estimated by the levels of nitrite present in the culture medium (Fig. 5A). We observed that MV, EX and CM significantly decreased the levels of nitrite in the medium and the mRNA expression of iNOS in OA chondrocytes compared with cells treated with IL-1 $\beta$ alone.

\section{Effects on MMPs}

In order to evaluate the effects of treatments on total MMP activity, a fluorometric assay was performed as indicated in Materials and methods. Fig. 5B shows that OA chondrocyte 
Fig. 5. NO production and iNOS gene expression (A), MMP activity and MMP-13 gene expression (B) in OA chondrocytes. Nitrite levels and MMP activity were measured by fluorometry in cell culture supernatants. iNOS and MMP-13 mRNA expression was determined by real-time PCR as indicated in materials and methods. Cultures were treated with IL- $1 \beta$ alone or in combination with EV or CM from AD-MSC for $24 \mathrm{~h}$ (mean \pm SEM from 4 (A) or 3 (B) separate experiments with cells from separate donors). FU, fluorescence units. ${ }^{++} \mathrm{P}<0.01$ compared to control (non-stimulated cells); $* \mathrm{P}<0.05, \quad * * \mathrm{P}<0.01$ compared to IL-1 $\beta$; \#\# $\mathrm{P}<0.01$ compared to CM.
A
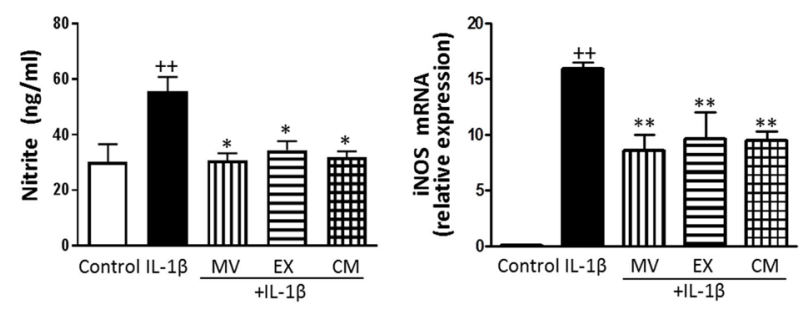

B
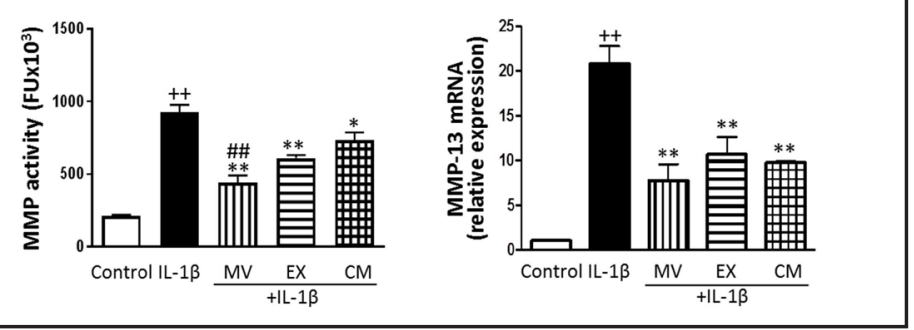

stimulation with IL-1 $\beta$ resulted in increased MMP activity in the culture medium. All treatments significantly reduced this activity and MV exerted a stronger effect compared with CM. MMP-13 (collagenase 3) has been implicated in the early phase of chondrocyte-mediated cartilage collagen breakdown [26]. A consistent induction of MMP13 gene expression was seen following IL-1 $\beta$ stimulation of OA chondrocytes whereas treatment with MV, EX or CM significantly decreased it.

\section{Effects on collagen II expression}

It is known that IL-1 $\beta$ suppress the transcription of the chondrocyte-specific marker collagen type II [4] and induces its degradation [27]. Fig. 6 shows that when IL-1 $\beta$ and EV or CM were present in the culture medium, these treatments significantly relieved the IL-1 $\beta$-induced suppression of chondrocyte-specific collagen type II expression. Interestingly, MV were significantly more effective than EX or CM leading to a level of collagen II close to that of control chondrocytes (non-stimulated cells).

\section{Effects on transcription factors}

The transcription factor NF- $\kappa \mathrm{B}$ mediates many of the downstream effects of IL- $1 \beta$ activating the transcription of pro-inflammatory and catabolic molecules. We have studied the effects of MV, EX and CM on the binding of p65 to DNA in the nucleus of OA chondrocytes stimulated with IL-1 $\beta$. There was a marked enhancement of p65-DNA binding by this cytokine (Fig. 7A) which was significantly reduced by $\mathrm{MV}, \mathrm{CM}$ and to a lesser extent by EX. AP-1 also plays an important role in MMP 


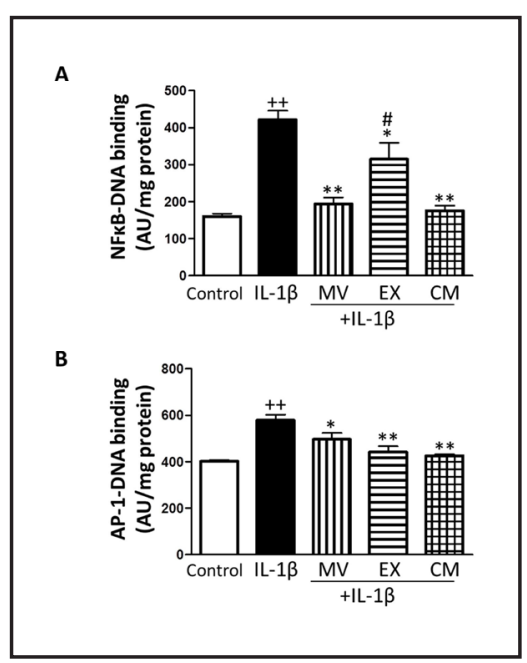

Fig. 7. Activation of transcription factors in OA chondrocytes. P65 NF$\kappa B(A)$ and c-jun AP-1 (B) binding to DNA was measured by ELISA and expressed as arbitrary units (AU) per mg of protein. Cultures were treated with IL-1 $\beta$ alone or in combination with EV or CM from AD-MSC for $1 \mathrm{~h}$. Results are expressed as mean \pm SEM from 4 separate experiments with cells from separate donors. ${ }^{++} \mathrm{P}<0.01$ compared to control (non-stimulated cells); ${ }^{*} \mathrm{P}<0.05,{ }^{* *} \mathrm{P}<0.01$ compared to IL-1 $\beta$; ${ }^{*} \mathrm{P}<0.05$ compared to CM.

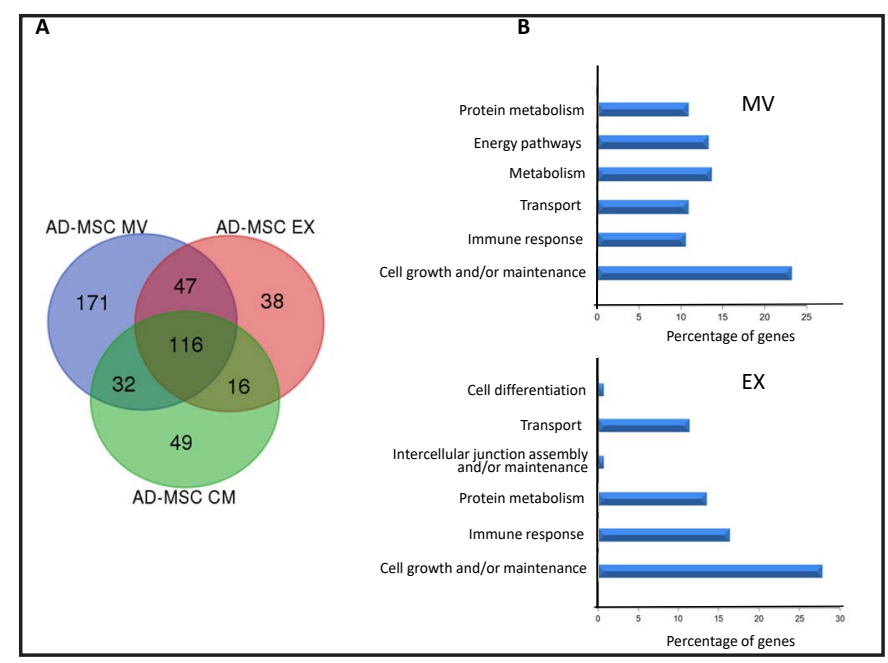

Fig. 8. Proteome characterization of EV from AD-MSC. A: Venn diagram. The number present in the circle represents the total number of identified proteins in particular data sets. B: Most over-represented biological processes (gene ontology terms) present in EV proteomes.

Table 1. Over-represented proteins in AD-MSC EV compared to CM

\begin{tabular}{lll}
\hline Identified protein & Uniprot ID & Main function \\
\hline MV & & \\
Annexin A1 & P04083 & Immunomodulation \\
Apolipoprotein H & P02749 & Negtive substrate binding \\
Butyryl-Cholinesterase & P06276 & Esterase activity \\
CD81 & P60033 & Endocytic trafficking \\
Dermokine & Q6E0U4 & Keratinocyte differentiation \\
Fermitin family homolog 3 & Q86UX7 & Integrin activation \\
Integrin $\beta 1$ & P05556 & Cell-matrix collagen binding \\
Peroxiredoxin 6 & P30041 & Peroxidase/Phospholipase A2 \\
Phosphoglycerate mutase 1 & P18669 & Canonical glycolysis \\
Junction Plakoglobin & P14923 & $\alpha$-catenin binding \\
Rab GDP dissociation inhibitor & P50395 & Rab regulation \\
Tropomyosin 1 & P09493 & Actin binding \\
Tropomyosin 3 & P06753 & Actin binding \\
$\alpha$-Actinin 4 & O43707 & Actin binding \\
$\alpha$-Enolase & P06733 & Canonical glycolysis \\
EX & & \\
Carboxypeptidase N & P15169 & Inflammatory peptides degradation \\
HSP70 & P11142 & Molecular chaperone \\
Pregnancy-zone protein & F5GXY0 & Endopeptidase inhibitor \\
\hline
\end{tabular}

transcription induced by cytokines [1]. DNA binding of c-Jun AP-1 was significantly activated by IL-1 $\beta$ (Fig. 7B) while treatment with MV, EX or CM significantly decreased this process.

\section{Proteomic analysis of AD-MSC EV}

We performed a proteomic analysis of AD-MSC EV in order to identify their protein content and possible active components. 365 proteins were found in MV preparations, 217 in EX and 213 in CM. Fig. 8A shows the Venn diagram indicating that 116 proteins were identified in MV, EX and CM. MV had a higher number of unshared proteins compared with EX (171 vs. 38). These proteins are involved in different cellular process, mainly cellular growth and/or maintenance, immune response, protein metabolism and transport (Fig. 8B). When compared with CM proteome, 42 unique proteins were identified in MV with a $P$ value $<0.01$. Of them, 15 (Table 1) were over-represented with a fold-change of at least 2.5. Among EX proteins, 28 were found significantly different from the CM proteome, but only 3 were over-represented with a fold change of at least 2.5. 


\section{Cellular Physiology Cell Physiol Biochem 2018;47:11-25 \begin{tabular}{ll|l} 
and Biochemistry Published onIIne: IVlay 15, 2018 & $\begin{array}{l}\text { (C) } 2018 \text { The Author(s). Published by S. Karger AG, Basel } \\
\text { www.karger.com/cpb }\end{array}$ \\
\hline
\end{tabular}

Fig. 9. Annexin A1 expression (A) and IL-6 production after annexin A1 blockade (B) in OA chondrocytes. A: Protein expression was determined by immunofluorescence. Cultures were treated with IL-1 $\beta$ alone or in combination with EV or CM from AD-MSC for $24 \mathrm{~h}$. Results are expressed as mean \pm SEM from 4 separate experiments with cells from separate donors. FD: fluorescence density. ${ }^{+} \mathrm{P}<0.05$ compared to control (non-stimulated cells); ${ }^{* *} \mathrm{P}<0.01$ compared to IL-1 $\beta$. ${ }^{\&} \mathrm{P}<0.01$ compared to MV. Bar $=30 \mu \mathrm{m}$. B: IL-6 was measured by ELISA in cell culture supernatants. Cultures were treated with IL-1 $\beta$ alone or in combination with MV from AD-MSC after annexin A1 blockade with a specific antibody or without blockade. Results are expressed as mean \pm SEM from 3 separate experiments with cells from separate donors. ${ }^{++} \mathrm{P}<0.01$ compared to control (non-stimulated cells); ${ }^{* *} \mathrm{P}<0.01$ compared to IL-1 $\beta$.

\section{Effects on annexin A1}

We have studied CM and EV effects on the expression of annexin A1. This protein is over-represented in MV (Table 1) and has demonstrated immunomodulatory and anti-inflammatory properties in different systems (reviewed in [28]). Fig. 9A shows that annexin A1 expression was significantly enhanced by treatment of chondrocytes with all fractions and mainly with MV. To explore the possibility that annexin A1 may contribute to the observed anti-inflammatory and chondroprotective effects, we neutralized this protein in the fraction showing the highest expression using a specific antibody and determined the consequences on the production of the inflammatory cytokine IL-6 and the expression of collagen II in OA chondrocytes in the presence ofIL-1 $\beta$. Annexin A1 blockade significantly reverted the inhibitory effects of MV on the inflammatory cytokine IL-6 (Fig. 9B) and the enhancement of type II collagen (Fig. 10).

\section{Discussion}

A wide range of evidence indicates that paracrine effects of MSC are a central mechanism of cell therapy promoting tissue
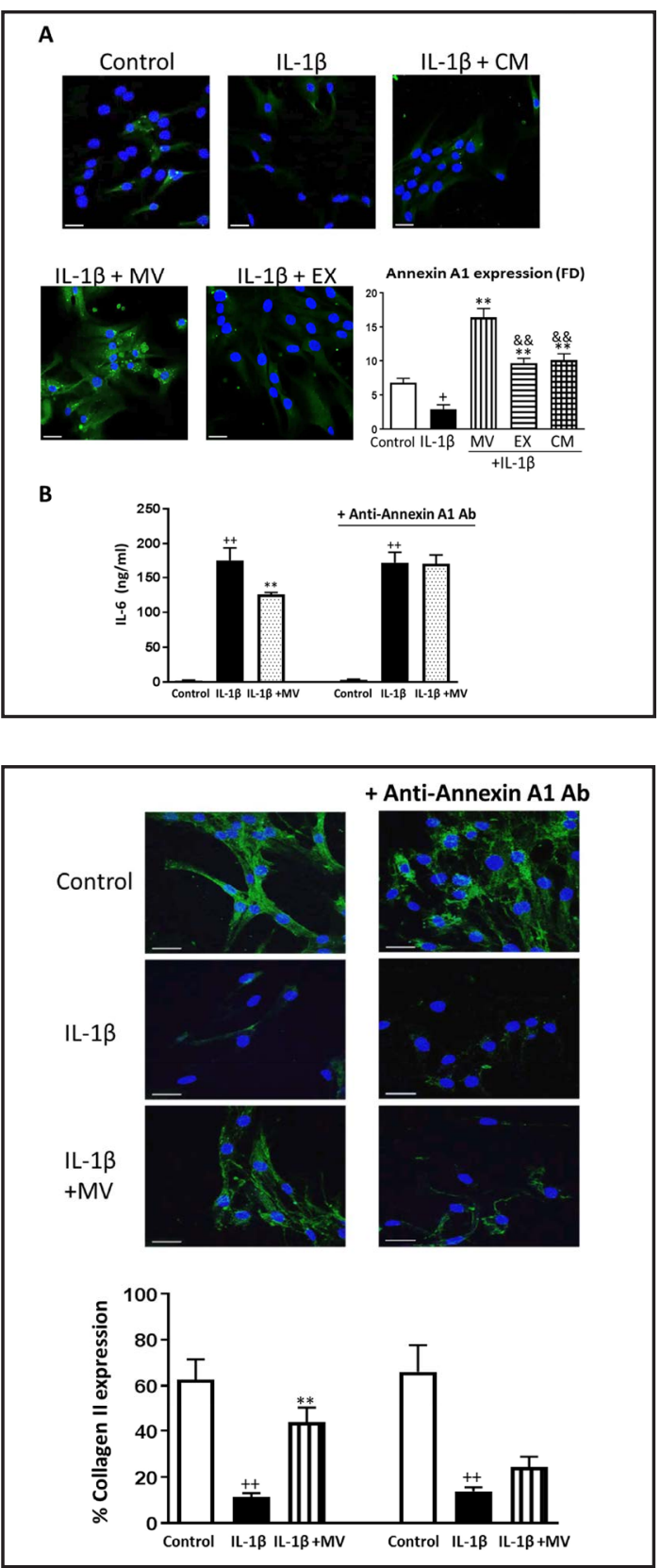

Fig. 10. Collagen II expression after annexin A1 blockade. Collagen II protein expression was determined by immunofluorescence. Cultures were treated with IL-1 $\beta$ alone or in combination with MV from AD-MSC after annexin A1 blockade with a specific antibody or without blockade. Results are expressed as mean \pm SEM from 3 separate experiments with cells from separate donors. ${ }^{++} \mathrm{P}<0.01$ compared to control (non-stimulated cells); ${ }^{* *} \mathrm{P}<0.01$ compared to IL-1 $\beta$. Bar $=30 \mu \mathrm{m}$. regeneration $[29,30]$. In line with this view, we have previously shown that CM from ADMSC exhibits anti-inflammatory properties in OA chondrocytes [20]. In the present work, we 
have characterized the EV present in this CM and assessed their possible contribution to its protective actions.

Synovitis and pro-inflammatory mediators are present in early-stage and late-stage $\mathrm{OA}$ (reviewed in [31]) and participate in a positive inflammatory feedback loop in the joint between synoviocytes and chondrocytes likely involving EV [32]. In OA cartilage, IL-1 $\beta$ and $\mathrm{TNF} \alpha$ induce a wide range of pro-inflammatory mediators such as cytokines, chemokines, $\mathrm{PGE}_{2}$, NO and degradative enzymes [31,33]. Therefore, inflammation is associated to progression of cartilage damage in $\mathrm{OA}$ and different mediators synergize to amplify and perpetuate the process. Our results have shown that MV and EX present in CM from ADMSC exert anti-inflammatory effects similar to CM. In contrast, EV from HaCaT cells were completely ineffective on cytokine production in $\mathrm{OA}$ chondrocytes and explants confirming the specificity of the observed effects. The downregulation of the pro-inflammatory cytokines TNF $\alpha$ and IL- 6 may have implications for the control of altered chondrocyte metabolism. Interestingly, IL-6 has been involved in OA pathophysiology [34] and increased circulating levels of IL- 6 have been associated to radiographic knee OA [35].

MV and EX were also able to counteract the inhibitory effects of IL-1 $\beta$ on the antiinflammatory cytokine IL-10. MV treatment determined a significant IL-10 enhancement compared with EX, which may be related to its content of annexin A1 [36]. The increased production of IL-10 may then contribute to the anti-inflammatory effects of CM and its EV as this cytokine inhibits the synthesis of pro-inflammatory cytokines [37] and antagonizes their deleterious effects on chondrocyte metabolism [38, 39].

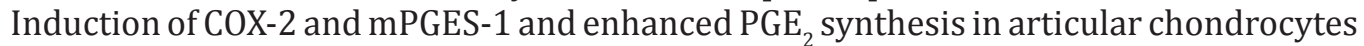
lead to anti-anabolic and degradative effects in the joint [25, 40,41]. Our results indicate that $\mathrm{MV}$ and EX are able to control the levels of this eicosanoid through the downregulation of COX-2 and mPGES-1. In addition, MV and EX decreased iNOS induction and NO production, thus preventing the effects of this mediator on the induction and activation of MMPs and the inhibition of extracellular matrix synthesis [42].

The actions of inflammatory mediators in chondrocytes also result in a reduced collagen II expression in OA chondrocytes [27]. Our data indicate that EV from AD-MSC protect OA chondrocytes from the negative effects of IL- $1 \beta$ on collagen II. These findings suggest a role for $\mathrm{EV}$ as protective mediators of the differentiated chondrocyte phenotype in inflammatory conditions. Components of extracellular matrix and inflammatory mediators stimulate the degradation of cartilage by inducing different catabolic enzymes. We have shown that MV and to a lesser extent EX, reduced the release of MMP activity. This was accompanied by a significant reduction in gene expression of MMP-13 which plays a key role in collagen II degradation [43]. Taken as a whole, our results suggest that MV may provide better chondroprotection than EX or CM from AD-MSC.

In $\mathrm{OA}$ chondrocytes, canonical NF- $\kappa \mathrm{B}$ signaling mediates the induction of inflammatory mediators and catabolic mechanisms as well as cellular differentiation changes which favor the onset and perpetuation of disease [44, 45]. A reduction in the activation of this transcription factor by CM and EV could contribute to the observed downregulation of IL6, TNF $\alpha$, COX-2, iNOS and MMPs [46]. There is a significant crosstalk of NF- $\mathrm{kB}$ with other signaling pathways relevant in OA chondrocytes. In particular, AP-1 cooperates with NF- $\mathrm{B}$ in the induction of MMP-13 and other MMPs $[1,47]$. Furthermore, IL-1 $\beta$ suppresses collagen II expression in articular chondrocytes by inducing the activation of AP-1 and subsequent suppression of Sox-9 contributing to the loss of the differentiated chondrocyte phenotype [48]. We have shown that MV and EX decrease the DNA binding activities of AP-1 and NF$\kappa B$ with an effect of MV similar to CM and higher than EX on the last transcription factor. Therefore, the downregulation of MMP activity and MMP-13 gene expression may be the consequence of a decreased activation of both transcription factors.

Proteomic analysis indicated the presence of unique proteins in MV and EX fractions of AD-MSC CM, and some of them can play a role in the regulation of inflammatory processes and immune responses. In particular, annexin A1 is over-represented in MV and exerts complex anti-inflammatory and pro-resolution effects. In addition to the inhibition of different 


\section{Cellular Physiology Cell Physiol Biochem 2018:47:11-25 and Biochemistry Publishe.1159/000489739 $2018 \quad \begin{aligned} & \text { DOI: } 2018 \text { The Author(s). Published by S. Karger AG, Basel } \\ & \text { www.karger.com/cpb }\end{aligned}$ \\ Tofiño-Vian et al.: Chondroprotective Actions of AD-MSC MV}

inflammatory mediators, annexin A1 exerts suppressive effect on cells of the immune system (reviewed in [49]). EV represent a way of cellular communication and transfer of components which may be exploited for therapeutic purposes. In this regard, annexin A1 is secreted, at least in part, in EV by different cell types such as neutrophils [50] or human bone marrow mesenchymal stem cells [51] and it can be delivered into the recipient cell [50, 52]. Although further studies are needed to assess the possible contribution of other components of AD-MSC EV, our data suggest that annexin A1 may contribute to the anti-inflammatory and chondroprotective effects of these microparticles under inflammatory stress conditions. These findings are in line with the report that neutrophil MV expressing annexin A1 enhanced chondrocyte anabolic properties in vitro, and after in vivo administration to mice protected against cartilage degradation in a model of inflammatory arthritis [50].

\section{Conclusion}

In summary, we have shown that MV and EX present in the CM of AD-MSC modulate chondrocyte metabolism to counteract the effects of IL-1 $\beta$. Therefore, EV can reproduce the anti-inflammatory properties of CM from AD-MSC in OA chondrocytes. Our findings are consistent with the hypothesis that EV are mediators of AD-MSC chondroprotective actions with a main role for MV. These EV may play important regulatory roles during cell communication and represent a novel strategy to develop potential treatments in joint conditions.

\section{Acknowledgements}

This work was supported by grants SAF2013-4874R (MINECO, FEDER) and PROMETEOII/2014/071 (Generalitat Valenciana), Spain.

\section{Disclosure statement}

The authors declare to have no conflict of interests.

\section{References}

1 Mengshol JA, Vincenti MP, Coon CI, Barchowsky A, Brinckerhoff CE: Interleukin-1 induction of collagenase 3 (matrix metalloproteinase 13) gene expression in chondrocytes requires p38, c-Jun N-terminal kinase, and nuclear factor kappaB: differential regulation of collagenase 1 and collagenase 3. Arthritis Rheum 2000;43:801-811.

-2 Tetlow LC, Adlam DJ, Woolley DE: Matrix metalloproteinase and proinflammatory cytokine production by chondrocytes of human osteoarthritic cartilage: associations with degenerative changes. Arthritis Rheum 2001;44:585-594.

- 3 Attur MG, Patel IR, Patel RN, Abramson SB, Amin AR: Autocrine production of IL-1 beta by human osteoarthritis-affected cartilage and differential regulation of endogenous nitric oxide, IL-6, prostaglandin E2, and IL-8. Proc Assoc Am Physicians 1998;110:65-72.

4 Goldring MB, Birkhead J, Sandell LJ, Kimura T, Krane SM: Interleukin 1 suppresses expression of cartilagespecific types II and IX collagens and increases types I and III collagens in human chondrocytes. J Clin Invest 1988;82:2026-2037.

5 Pers YM, Ruiz M, Noël D, Jorgensen C: Mesenchymal stem cells for the management of inflammation in osteoarthritis: state of the art and perspectives. Osteoarthritis Cartilage 2015;23:2027-2035.

-6 ter Huurne M, Schelbergen R, Blattes R, Blom A, de Munter W, Grevers LC, Jeanson J, Noël D, Casteilla L, Jorgensen C, van den Berg W, van Lent PLEM: Antiinflammatory and chondroprotective effects of intraarticular injection of adipose-derived stem cells in experimental osteoarthritis. Arthritis Rheum 2012;64:3604-3613.

7 Desando G, Cavallo C, Sartoni F, Martini L, Parrilli A, Veronesi F, Fini M, Giardino R, Facchini A, Grigolo B: Intra-articular delivery of adipose derived stromal cells attenuates osteoarthritis progression in an experimental rabbit model. Arthritis Res Ther 2013;15:R22. 


\section{Cellular Physiology Cell Physiol Biochem 2018;47:11-25

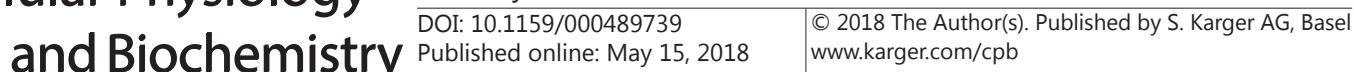 \\ Tofiño-Vian et al.: Chondroprotective Actions of AD-MSC MV}

8 Wang Y, Chen X, Cao W, Shi Y: Plasticity of mesenchymal stem cells in immunomodulation: pathological and therapeutic implications. Nat Immunol 2014;15:1009-1016.

-9 van Buul GM, Villafuertes E, Bos PK, Waarsing JH, Kops N, Narcisi R, Weinans H, Verhaar JA, Bernsen MR, van Osch GJ: Mesenchymal stem cells secrete factors that inhibit inflammatory processes in short-term osteoarthritic synovium and cartilage explant culture. Osteoarthritis Cartilage 2012;20:1186-1196.

10 Manferdini C, Maumus M, Gabusi E, Piacentini A, Filardo G, Peyrafitte JA, Jorgensen C, Bourin P, Fleury-Cappellesso S, Facchini A, Noel D, Lisignoli G: Adipose-derived mesenchymal stem cells exert antiinflammatory effects on chondrocytes and synoviocytes from osteoarthritis patients through prostaglandin E2. Arthritis Rheum 2013;65:1271-1281.

11 Mause SF, Weber C: Microparticles: protagonists of a novel communication network for intercellular information exchange. Circ Res 2010;107:1047-1057.

12 Colombo M, Raposo G, Théry C: Biogenesis, secretion, and intercellular interactions of exosomes and other extracellular vesicles. Annu Rev Cell Dev Biol 2014;30:255-289.

13 Lai RC, Chen TS, Lim SK: Mesenchymal stem cell exosome: a novel stem cell-based therapy for cardiovascular disease. Regen Med 2011;6:481-492.

14 Maumus M, Jorgensen C, Noel D: Mesenchymal stem cells in regenerative medicine applied to rheumatic diseases: Role of secretome and exosomes. Biochimie 2013;95:2229-2234.

15 Furuta T, Miyaki S, Ishitobi H, Ogura T, Kato Y, Kamei N, Miyado K, Higashi Y, Ochi M: Mesenchymal Stem Cell-Derived Exosomes Promote Fracture Healing in a Mouse Model. Stem Cells Transl Med 2016;5:16201630.

16 Sarko DK, McKinney CE: Exosomes: Origins and Therapeutic Potential for Neurodegenerative Disease. Front Neurosci 2017;11:82.

17 Zhang B, Yin Y, Lai RC, Tan SS, Choo AB, Lim SK: Mesenchymal stem cells secrete immunologically active exosomes. Stem Cells Dev 2014;23:1233-1244.

18 Zhang S, Chu WC, Lai RC, Lim SK, Hui JH, Toh WS: Exosomes derived from human embryonic mesenchymal stem cells promote osteochondral regeneration. Osteoarthritis Cartilage 2016;24:2135-2140.

19 Tao SC, Yuan T, Zhang YL, Yin WJ, Guo SC, Zhang CQ: Exosomes derived from miR-140-5p-overexpressing human synovial mesenchymal stem cells enhance cartilage tissue regeneration and prevent osteoarthritis of the knee in a rat model. Theranostics 2017;7:180-195.

20 Platas J, Guillen MI, del Caz MD, Gomar F, Mirabet V, Alcaraz MJ: Conditioned media from adipose tissuederived mesenchymal stem cells down-regulate degradative mediators induced by interleukin-1â in osteoarthritic chondrocytes. Mediators Inflamm 2013;2013/357014:

-21 Platas J, Guillen MI, Perez Del Caz MD, Gomar F, Castejon MA, Mirabet V, Alcaraz MJ: Paracrine effects of human adipose-derived mesenchymal stem cells in inflammatory stress-induced senescence features of osteoarthritic chondrocytes. Aging (Albany NY) 2016;8:1703-1717.

-22 Vogel R, Coumans FA, Maltesen RG, Boing AN, Bonnington KE, Broekman ML, Broom MF, Buzas EI, Christiansen G, Hajji N, Kristensen SR, Kuehn MJ, Lund SM, Maas SL, Nieuwland R, Osteikoetxea X, Schnoor R, Scicluna BJ, Shambrook M, de VJ, Mann SI, Hill AF, Pedersen S: A standardized method to determine the concentration of extracellular vesicles using tunable resistive pulse sensing. J Extracell Vesicles 2016;5:31242.

23 Moroney MA, Alcaraz MJ, Forder RA, Carey F, Hoult JRS: Selectivity of neutrophil 5-lipoxygenase and cyclooxygenase inhibition by an anti-inflammatory flavonoid glycoside and related aglycone flavonoids. J Pharm Pharmacol 1988;40:787-792.

24 Misko TP, Schilling RJ, Salvemini D, Moore WM, Currie MG: A fluorometric assay for the measurement of nitrite in biological samples. Anal Biochem 1993;214:11-16.

25 Li X, Afif H, Cheng S, Martel-Pelletier J, Pelletier JP, Ranger P, Fahmi H: Expression and regulation of microsomal prostaglandin E synthase-1 in human osteoarthritic cartilage and chondrocytes. J Rheumatol 2005;32:887-895.

-26 Koshy PJ, Lundy CJ, Rowan AD, Porter S, Edwards DR, Hogan A, Clark IM, Cawston TE: The modulation of matrix metalloproteinase and ADAM gene expression in human chondrocytes by interleukin-1 and oncostatin M: a time-course study using real-time quantitative reverse transcription-polymerase chain reaction. Arthritis Rheum 2002;46:961-967.

27 Goldring MB, Otero M, Tsuchimochi K, Ijiri K, Li Y: Defining the roles of inflammatory and anabolic cytokines in cartilage metabolism. Ann Rheum Dis 2008;67 Suppl 3:iii75-iii82.

28 Perretti M, Dalli J: Exploiting the Annexin A1 pathway for the development of novel anti-inflammatory therapeutics. Br J Pharmacol 2009;158:936-946. 


\section{Cellular Physiology Cell Physiol Biochem 2018:47:11-25

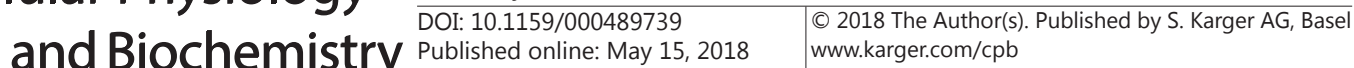 \\ Tofiño-Vian et al.: Chondroprotective Actions of AD-MSC MV}

29 Ratajczak MZ, Jadczyk T, Pedziwiatr D, Wojakowski W: New advances in stem cell research: practical implications for regenerative medicine. Pol Arch Med Wewn 2014;124:417-426.

-30 Hofer HR, Tuan RS: Secreted trophic factors of mesenchymal stem cells support neurovascular and musculoskeletal therapies. Stem Cell Res Ther 2016;7:131.

-31 Goldring MB, Otero M: Inflammation in osteoarthritis. Curr Opin Rheumatol 2011;23:471-478.

-32 Withrow J, Murphy C, Liu Y, Hunter M, Fulzele S, Hamrick MW: Extracellular vesicles in the pathogenesis of rheumatoid arthritis and osteoarthritis. Arthritis Res Ther 2016;18:286.

33 Chevalier X: Upregulation of enzymatic activity by interleukin-1 in osteoarthritis. Biomed Pharmacother 1997;51:58-62.

-34 Goekoop RJ, Kloppenburg M, Kroon HM, Frolich M, Huizinga TW, Westendorp RG, Gussekloo J: Low innate production of interleukin-1 beta and interleukin- 6 is associated with the absence of osteoarthritis in old age. Osteoarthritis Cartilage 2010;18:942-947.

35 Livshits G, Zhai G, Hart DJ, Kato BS, Wang H, Williams FM, Spector TD: Interleukin-6 is a significant predictor of radiographic knee osteoarthritis: The Chingford Study. Arthritis Rheum 2009;60:2037-2045.

-36 Headland SE, Norling LV: The resolution of inflammation: Principles and challenge. Semin Immunol 2015;27:149-160.

-37 Fernandes JC, Martel-Pelletier J, Pelletier JP: The role of cytokines in osteoarthritis pathophysiology. Biorheology 2003;39:237-246.

38 Wang Y, Lou S: Direct protective effect of interleukin-10 on articular chondrocytes in vitro. Chin Med J (Engl) 2001;114:723-725.

39 John T, Muller RD, Oberholzer A, Zreiqat H, Kohl B, Ertel W, Hostmann A, Tschoeke SK, Schulze-Tanzil G: Interleukin-10 modulates pro-apoptotic effects of TNF-alpha in human articular chondrocytes in vitro. Cytokine 2007; 40:226-234.

40 Hardy MM, Seibert K, Manning PT, Currie MG, Woerner BM, Edwards D, Koki A, Tripp CS: Cyclooxygenase 2-dependent prostaglandin E2 modulates cartilage proteoglycan degradation in human osteoarthritis explants. Arthritis Rheum 2002;46:1789-1803.

41 Li X, Ellman M, Muddasani P, Wang JH, Cs-Szabo G, Van Wijnen AJ, Im HJ: Prostaglandin E2 and its cognate EP receptors control human adult articular cartilage homeostasis and are linked to the pathophysiology of osteoarthritis. Arthritis Rheum 2009;60:513-523.

42 Lotz M: The role of nitric oxide in articular cartilage damage. Rheum Dis Clin North Am 1999;25:269-282.

43 Goldring MB, Otero M, Plumb DA, Dragomir C, Favero M, El HK, Hashimoto K, Roach HI, Olivotto E, Borzi RM, Marcu KB: Roles of inflammatory and anabolic cytokines in cartilage metabolism: signals and multiple effectors converge upon MMP-13 regulation in osteoarthritis. Eur Cell Mater 2011;21:202-220.

44 Chockalingam PS, Varadarajan U, Sheldon R, Fortier E, LaVallie ER, Morris EA, Yaworsky PJ, Majumdar MK: Involvement of protein kinase Czeta in interleukin-1beta induction of ADAMTS-4 and type 2 nitric oxide synthase via NF-kappaB signaling in primary human osteoarthritic chondrocytes. Arthritis Rheum 2007;56:4074-4083.

45 Olivotto E, Otero M, Marcu KB, Goldring MB: Pathophysiology of osteoarthritis: canonical NF-kappaB/ IKKbeta-dependent and kinase-independent effects of IKKalpha in cartilage degradation and chondrocyte differentiation. RMD Open 2015;1:e000061.

46 Rigoglou S, Papavassiliou AG: The NF-kappaB signaling pathway in osteoarthritis. Int J Biochem Cell Biol 2013;45:2580-2584.

47 Liacini A, Sylvester J, Li WQ, Zafarullah M: Inhibition of interleukin-1-stimulated MAP kinases, activating protein-1 (AP-1) and nuclear factor kappa B (NF-kappa B) transcription factors down-regulates matrix metalloproteinase gene expression in articular chondrocytes. Matrix Biol 2002;21:251-262.

-48 Hwang SG, Yu SS, Poo H, Chun JS: c-Jun/activator protein-1 mediates interleukin-1beta-induced dedifferentiation but not cyclooxygenase-2 expression in articular chondrocytes. J Biol Chem 2005;280:29780-29787.

49 D’Acquisto F, Perretti M, Flower RJ: Annexin-A1: a pivotal regulator of the innate and adaptive immune systems. Br J Pharmacol 2008;155:152-169.

50 Headland SE, Jones HR, Norling LV, Kim A, Souza PR, Corsiero E, Gil CD, Nerviani A, Dell'Accio F, Pitzalis C, Oliani SM, Jan LY, Perretti M: Neutrophil-derived microvesicles enter cartilage and protect the joint in inflammatory arthritis. Sci Transl Med 2015;7:315ra190.

-51 Kim HS, Choi DY, Yun SJ, Choi SM, Kang JW, Jung JW, Hwang D, Kim KP, Kim DW: Proteomic analysis of microvesicles derived from human mesenchymal stem cells. J Proteome Res 2012;11:839-849.

52 Leoni G, Nusrat A: Annexin A1: shifting the balance towards resolution and repair. Biol Chem 2016;397:971-979. 